\title{
Study of the Mechanical Behaviour of Mortars Modified with Rice Husk Ash
}

\author{
Issiaka Sanou ${ }^{1,2 *}$, Moustapha Sawadogo' ${ }^{1}$ Mohamed Seynou${ }^{1}$, Lamine Zerbo ${ }^{1}$, \\ Raguilnaba Ouedraogo ${ }^{1}$
}

${ }^{1}$ Laboratoire de Chimie Moléculaire et de Matériaux, équipe de physico-chimie et de Technologie des matériaux, UFR/Sciences Exactes et Appliquées, Université Joseph KI-ZERBO, Ouagadougou, Burkina Faso

${ }^{2}$ Laboratoire de Chimie et Energies Renouvelables, Unité de recherche en Physico-Chimie et Technologie des Matériaux UFR/Sciences et Techniques, Université Nazi BONI, Bobo-Dioulasso, Burkina Faso

Email: *sanoussiaka@yahoo.fr

How to cite this paper: Sanou, I., Sawadogo, M., Seynou, M., Zerbo, L. and Ouedraogo, R. (2019) Study of the Mechanical Behaviour of Mortars Modified with Rice Husk Ash. Journal of Minerals and Materials Characterization and Engineering, 7, 373-384.

https://doi.org/10.4236/jmmce.2019.76025

Received: September 2, 2019

Accepted: October 19, 2019

Published: October 22, 2019

Copyright $\odot 2019$ by author(s) and Scientific Research Publishing Inc. This work is licensed under the Creative Commons Attribution International License (CC BY 4.0).

http://creativecommons.org/licenses/by/4.0/

\section{(c) (i) Open Access}

\begin{abstract}
The purpose of this work is to study the influence of Rice Husk Ash (RHA) on the mechanical strength of mortars. For this purpose, ash was produced by calcining rice husk at $680^{\circ} \mathrm{C}$ for 5 hours to produce reactive pozzolan. The chemical and mineralogical composition studied by Inductively Coupled Plasma-Atomic Emission Spectrometry (ICP-AES) and X-Ray Diffraction (XRD) showed that this ash is rich in amorphous silica. The ash presents a good pozzolanic activity with a lime fixation rate of $100 \%$ after only 7 days of treatment. The addition of RHA to cement contributes to the formation of calcium silicate hydrate $(\mathrm{CSH})$ and calcium aluminate hydrate of $\mathrm{C}_{3} \mathrm{ASH}_{6}$ type. The presence of RHA in the mortars improves their mechanical strength. This improvement is due to the filler effect of RHA and to formation of the CSH resulting from the pozzolanic reactivity between the amorphous silica of the RHA and the portlandite released by hydration of the cement.
\end{abstract}

\section{Keywords}

Mortar, Rice Husk Ash, Mechanical Strength, Filler Effect, CSH

\section{Introduction}

Cement is a strategic product in the civil engineering for the construction of reinforced concrete structures. But its production generates around $5 \%$ of toxic gases such as $\mathrm{CO}_{2}$ responsible for the ecological environmental degradation of the planet [1]. Moreover the hydration of cement releases portlandite, which is 
responsible for the low resistance of mortars against aggressive environment like acid and sulfate solutions. In order to resolve the ecological and durability problems, partial substitutions of cement by so-called pozzolanic materials could be undertaken. A pozzolan is defined as a siliceous and aluminous material which, in itself, possesses little or no cementitious value but which will, in finely divided form in the presence of moisture, react chemically with calcium hydroxide at ordinary temperature to form compounds possessing cementitious properties [2]. The presence of pozzolan in a cement matrix causes a pozzolanic reaction between the portlandite of the cement and the amorphous silica of the vitreous phase of pozzolan. This leads to an increase in the formation of CSH, hydrates which are responsible for the resistance of cement products [3] [4] [5]. Among these pozzolanic materials, rice husk ash (RHA) has been the subject of several studies for its valorization as a supplementary cementitious material in concretes and mortars [6] [7] [8]. Rice husk ash is a by-product from the calcination of vegetable raw material of the rice husk. The rice husk obtained after hulling is most often abandoned in the fields and therefore constitutes an environmental waste. In order to address this storage problem and at the same time improve the properties of cement products, rice husks have been valued in this study. The objective of this paper is to study the influence of RHA on the mechanical strength of mortars. An emphasis will be put on the pozzolanic potentialities of RHA before it is used as pozzolan in the mortars formulation.

\section{Raw Materials and Experimental Methods}

\subsection{Characterization of Raw Materials}

The rice husk ash used in this study was obtained by calcining at $680^{\circ} \mathrm{C}$ a sample of rice husk taken from the rural commune of Bama, Burkina Faso. The calcination was conducted in a NABERTHERM C250 type furnace with a rise rate of $10^{\circ} \mathrm{C} / \mathrm{min}$ for 5 hours. The lime used for the saturated lime test consists mainly of calcium hydroxide (95\% pure). The cement whose chemical and mineralogical composition is recorded in Table 1, comes from the company Diamond Cement of Burkina Faso [9].

The chemical analysis of RHA was performed by ICP-AES. The chemical composition given in Table 1 shows that the rice husk ash consists mainly of silica for $96.84 \%$ by mass [10]. This value is slightly higher than the one given by the literature, which indicates a maximum of $96 \%$ by mass of silica [11]. RHA is low in alkalis because the sum of the alkaline oxides $\mathrm{Na}_{2} \mathrm{O}$ and $\mathrm{K}_{2} \mathrm{O}, 0.84 \%$ is lower than the minimum value of $0.95 \%$ given in the literature [11]. In addition, the sum of the oxides $\mathrm{SiO}_{2}, \mathrm{Al}_{2} \mathrm{O}_{3}$ and $\mathrm{Fe}_{2} \mathrm{O}_{3}$ is greater than the minimum value of $70 \%$ set by ASTM C-618 standard [12]. The glass content $\left(\mathrm{SiO}_{2}-\mathrm{CaO}\right)$ of $96.37 \%$ is well above the minimum value of $34 \%$. These results suggest that rice husk ash is a very reactive pozzolan. The total sum of the analyzed oxides (99.98\%) shows that it contains almost no carbon even at trace level. This low carbon content of RHA improves its pozzolanic responsiveness. The presence of 
significant amounts of carbon in the materials causes pore formation, and negatively influences the durability of the materials developed [8].

The RHA diffractogram (Figure 1) shows a large bump (halo) centered at about $22^{\circ}(2 \theta)$ indicating the presence of amorphous phases. Silica, the main element of rice husk ash, is then in amorphous form and will give good pozzolanic reactivity to RHA [13].

Before being used as a substitute for cement, the rice husk ash must have a certain so-called pozzolanic activity enabling it to react with the portlandite released by cement. This activity can be monitored by several methods.

Table 1. Chemical and mineralogical composition of the cement and RHA.

\begin{tabular}{|c|c|c|c|c|}
\hline \multicolumn{3}{|c|}{ Chemical composition (\%) } & \multirow{2}{*}{\multicolumn{2}{|c|}{ Mineralogy of cement (\%) }} \\
\hline Oxides & Cement & RHA & & \\
\hline $\mathrm{SiO}_{2}$ & 20.12 & 96.84 & & \\
\hline $\mathrm{Al}_{2} \mathrm{O}_{3}$ & 5.73 & 1.03 & & \\
\hline $\mathrm{Fe}_{2} \mathrm{O}_{3}$ & 4.06 & 0.38 & & \\
\hline $\mathrm{MgO}$ & 1.18 & 0.32 & $\mathrm{C}_{2} \mathrm{~S}$ & 15.68 \\
\hline $\mathrm{CaO}$ & 64.82 & 0.47 & & \\
\hline & & & $\mathrm{C}_{3} \mathrm{~A}$ & 8.31 \\
\hline $\mathrm{P}_{2} \mathrm{O}_{5}$ & 0.39 & - & & \\
\hline $\mathrm{SO}_{3}$ & 2.68 & - & & \\
\hline $\mathrm{Na}_{2} \mathrm{O}$ & 0.08 & 0.03 & & \\
\hline $\mathrm{K}_{2} \mathrm{O}$ & 0.17 & 0.81 & & \\
\hline $\mathrm{TiO}_{2}$ & - & 0.1 & F.L & 0.8 \\
\hline L.O.I & 0.27 & - & & \\
\hline
\end{tabular}

L.O.I: Loss On Ignition and F.L: Free Lime.

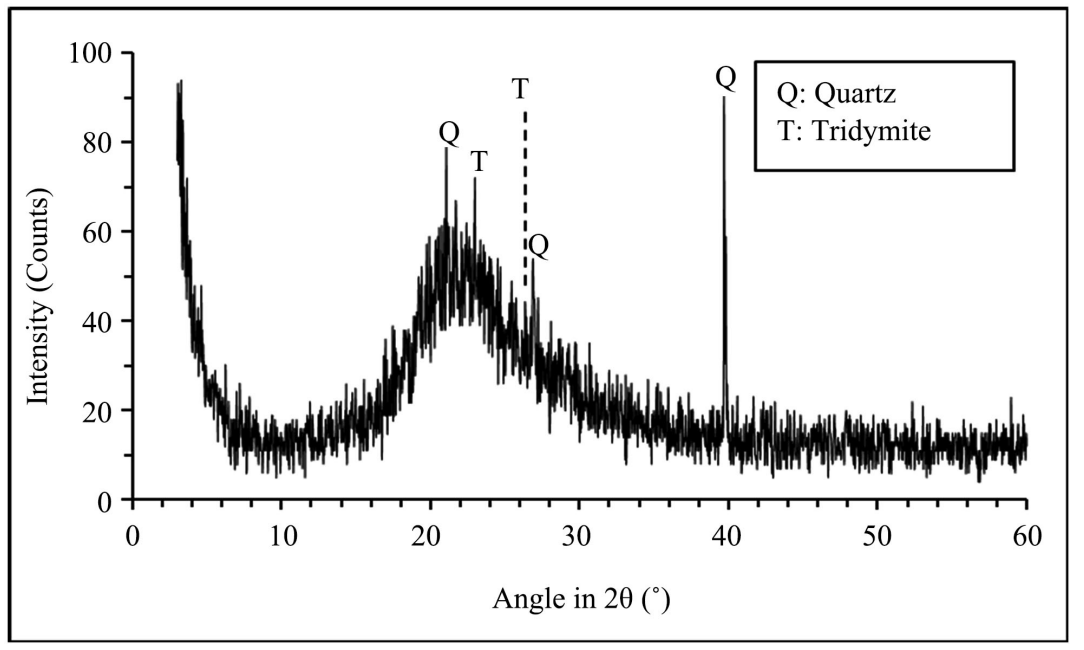

Figure 1. X-ray diffraction pattern of RHA. 


\subsection{Pozzolanic Activity}

\subsubsection{Chemicals Methods}

The Frattini test and the saturated lime test are the two chemicals methods used to determine the pozzolanic activity. First, the procedure of the Frattini test consists in preparing a mixture of $20 \mathrm{~g}$, consisting of $80 \%$ artificial portland cement (CPA) with $20 \%$ of RHA added to $100 \mathrm{~mL}$ of distilled water. The mixture is kept at a temperature of $40^{\circ} \mathrm{C}$ for eight days in hermetically sealed plastic boxes. After these eight days, the mixture is filtered through a pore size filter paper. The hydroxide ions $\left(\mathrm{OH}^{-}\right)$contained in the filtrate are then dosed with a dilute hydrochloric acid solution at $10^{-1} \mathrm{~mol} \cdot \mathrm{L}^{-1}$ using methyl orange as color indicator. Then the calcium ions $\left(\mathrm{Ca}^{2+}\right)$ will be as well dosed by an Ethylenediaminetetraacetate (EDTA) solution at $0.03 \mathrm{~mol} \cdot \mathrm{L}^{-1}$ using Patton and Reeders as a color indicator. The results obtained are illustrated by a graph giving the $\mathrm{Ca}^{2+}$ ions concentration expressed in mmol. $\mathrm{L}^{-1}$, which is equivalent to the amount of $\mathrm{CaO}$ according to the concentration of $\mathrm{OH}^{-}$ion also expressed in $\mathrm{mmol} \cdot \mathrm{L}^{-1}[14]$.

The saturated lime test consists in preparing a mixture consisting of $1 \mathrm{~g}$ of RHA and $75 \mathrm{~mL}$ of saturated lime solution initially prepared by dissolving $2 \mathrm{~g}$ of hydrated lime in $1 \mathrm{~L}$ of distilled water. The sealed mixture is kept during the test period set at 1,3, and 7 days. The test is carried out from $10 \mathrm{~mL}$ of filtered mixture. The $\mathrm{OH}^{-}$and $\mathrm{Ca}^{2+}$ ions are respectively dosed with dilute hydrochloric acid solution and EDTA using the same procedure as in the Frattini test. Thus, from the quantity of calcium ions contained in the initial mixture, the amount of $\mathrm{CaO}$ fixed by the material is determined.

\subsubsection{Mineralogical Reactivity}

After the Frattini test, the residues obtained were finely ground and then subjected to analysis. Qualitatively, thermogravimetric analysis (DTA/TG) was used to monitor not only the evolution of pozzolanic reactivity but also to identify the products resulting from pozzolanic reactivity. The thermograms DTA/TG are recorded using a Linseis apparatus operating under an air atmosphere at a heating rate of $10^{\circ} \mathrm{C} / \mathrm{min}$.

\subsection{Formulation of Mortars}

First the cement, the RHA ground to $80 \mu \mathrm{m}$ and water (225 g) are introduced into a mixing machine to be mixed for one minute at a speed of 140 revolutions per min. After that, the standardized sand ( $1350 \mathrm{~g})$ is added and the mixture is then mixed again for 3 minutes at a speed of 280 revolutions per min. The mixture is introduced into $4 \times 4 \times 160 \mathrm{~cm}^{3}$ prismatic molds and mechanically compacted using a shock wave apparatus. The molds containing the samples are covered with plastic film and stored in the cold storage with a temperature of $20^{\circ}$ $\pm 1^{\circ} \mathrm{C}$. Demolding is carried out after a period of 24 hours and the specimens are stored in the laboratory at $20^{\circ} \mathrm{C} \pm 1{ }^{\circ} \mathrm{C}$ in a vessel containing water until the day of the test set at 28 days [15]. Table 2 and Figure 2 respectively show the composition and the images of the various mortars produced. 


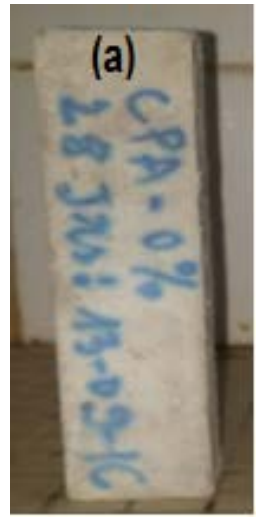

(a) mortar $\mathrm{B}_{0}$,

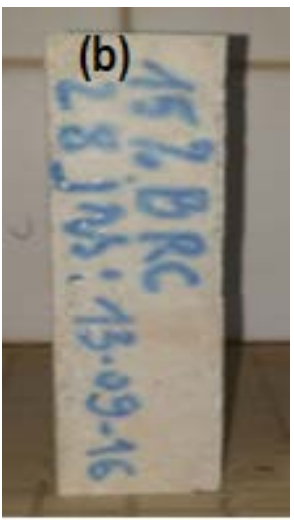

(b) mortar $\mathrm{B}_{15}$,

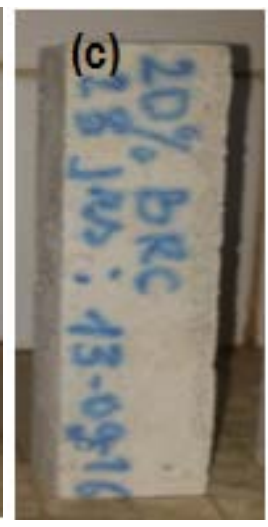

(c) mortar $\mathrm{B}_{20}$

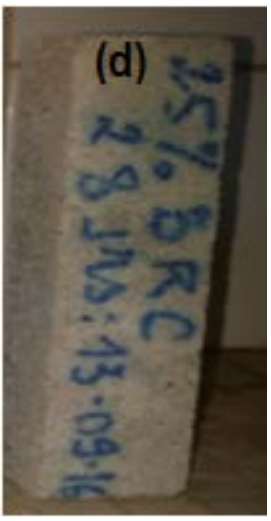

(d) mortar $\mathrm{B}_{25}$

Figure 2. Images of the mortars produced.

Table 2. Composition of mortars.

\begin{tabular}{ccc}
\hline Mortars & Cement (g) & RHA (g) \\
\hline $\mathrm{B}_{0}$ & 450 & 0 \\
$\mathrm{~B}_{15}$ & 382.5 & 67.5 \\
$\mathrm{~B}_{20}$ & 360 & 90 \\
$\mathrm{~B}_{25}$ & 337.5 & 112.5 \\
\hline
\end{tabular}

\subsection{Mechanical Strength}

The compressive and flexural strength are the mechanical parameters of our mortars that have been evaluated. The flexural strength is carried out on the $4 \times$ $4 \times 16 \mathrm{~cm}^{3}$ mortars with a hydraulic press equipped with a $200 \mathrm{kN}$ load cell at a controlled displacement rate of $0.5 \mathrm{~mm} / \mathrm{min}$. Equation (1) makes it possible to determine the limit stress in flexural strength [16]:

$$
\sigma=\frac{3 F E}{2 l e^{2}}
$$

$F$ is the intensity of the force applied, $E$ is the distance between the two specimen supports, $l$ is the width of the specimens, $e$ is its thickness and $\sigma$ is the stress at break.

In order to determine the compressive strength, the half-prism resulting from the flexural strength is subjected to a monotonously increasing load until breaking. Thus, the compressive strength is the ratio of the breaking load to the cross section of the specimen. The value of the resistance $R_{C}$ is obtained from Equation (2):

$$
R_{C}=\frac{P}{S}
$$

With: $S$ average value of the section in $\mathrm{cm}^{2}$ and $P$ the load in $\mathrm{kN}$. The flexural and compression strength tests are carried out in accordance with standard NF P 15-471 [17]. The images examination of mortars was performed with the Hitachi S2500 scanning electron microscopy (SEM). 


\section{Results and Discussion}

\subsection{Pozzolanic Activity}

\subsubsection{Frattini Test}

Figure 3 gives the solubility curve of the portlandite and the position of RHA and CPA cement with respect to this curve. From this figure it follows that the CPA located above the solubility curve has no pozzolanic activity. While the RHA located below this same curve has a pozzolanic character [18].

The Frattini test shows that the RHA has a pozzolanic activity. In order to follow the kinetics of the pozzolanic activity of the RHA, the saturated lime test was carried out.

\subsubsection{Saturated Lime Test}

The results of the saturated lime test are shown in Figure 4. At a young age (1 and 3 days), the amount of lime fixed by the RHA is important, even approaching $95 \%$ on the third day. This indicates rapid kinetics. From only 7 days onwards, all the lime is fixed by the ash. The high pozzolanic reactivity of this material is mainly due to the combined effect of the high silica content and the fineness of the RHA. According to Massazza, the pozzolanic reactivity is mainly controlled by the composition of active oxides of silica and alumina [19]. However some authors suggest that the chemical composition does not really affect pozzolanic reactivity [20]. Moreover, the increase in its specific surface causes a decrease in the size of its particles, which exposes its upper surface to the chemical reaction thus favoring its pozzolanic reactivity. The amorphous character is also a parameter influencing pozzolanic reactivity. The diffractogram of the RHA (Figure 1) by the broad amorphization hump shows that it consists of amorphous phase. According to Walker and S. Pavia, the dominant factor that determines pozzolanic activity is the amorphous character [20].

\subsubsection{Mineralogical Reactivity}

The reaction of portland cement with water results in the formation of different hydration products. The released portlandite is required for the pozzolanic reaction. This portlandite, in the presence of active pozzolanic materials can lead to the formation of new hydration products similar to those formed by the hydration of cement. Thus, after the Frattini test, the residues obtained were finely ground and their DTA/TG thermograms were realized. The different endothermic peaks observed on the thermograms (Figure 5 and Figure 6) can be attributed to a hydrated phase. Thus the first two endothermic respectively at temperatures at $70^{\circ} \mathrm{C}$ and $95^{\circ} \mathrm{C}$ for the cement alone correspond to the departure of hygroscopic water. The peak around $135^{\circ} \mathrm{C}$ observed on both DTA thermograms corresponds to the dehydration CSH [21]. This peak is greater in the mixture containing RHA, equally associated with a high mass loss. This suggests a much larger presence of $\mathrm{CSH}$ gels in this mixture. The calcium silicate hydrates result from the pozzolanic reaction between the amorphous silica $\left(\mathrm{SiO}_{2}\right)$ and the portlandite $(\mathrm{CH})$ released by the hydration of the cement according to the Reactions 1,2 and 3 [4]: 


$$
\mathrm{Ca}(\mathrm{OH})_{2} \leftrightarrow \mathrm{Ca}^{2+}+2 \mathrm{OH}^{-} \text {: dissolution of portlandite }
$$

$\mathrm{SiO}_{2}$ (amorphous silica of RHA $)+2 \mathrm{OH}-($ hydroxyl of portlandite $) \mathrm{H}_{2} \mathrm{SiO}_{4}^{2-}$

$x \mathrm{Ca}^{2+}+\mathrm{H}_{2} \mathrm{SiO}_{4}{ }^{2-}+2(x-1) \mathrm{OH}^{-}+(y-x) \mathrm{H}_{2} \mathrm{O} \rightarrow(\mathrm{CaO})_{x}\left(\mathrm{SiO}_{2}\right)\left(\mathrm{H}_{2} \mathrm{O}\right)_{y}\left[\mathrm{C}_{x} \mathrm{SH}_{y}\right]$ (3)

With: $\mathrm{CaO}=\mathrm{C} ; \mathrm{SiO}_{2}=\mathrm{S}$ and $\mathrm{H}_{2} \mathrm{O}=\mathrm{H}$.

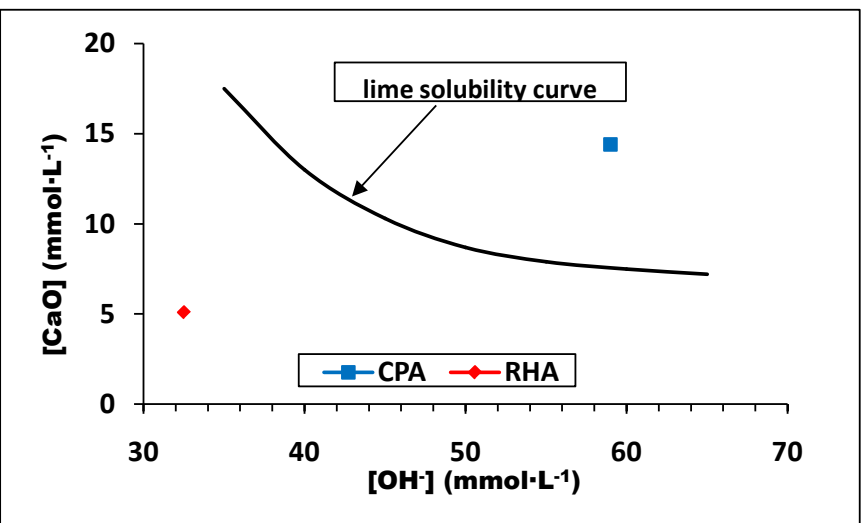

Figure 3. Frattini test results.

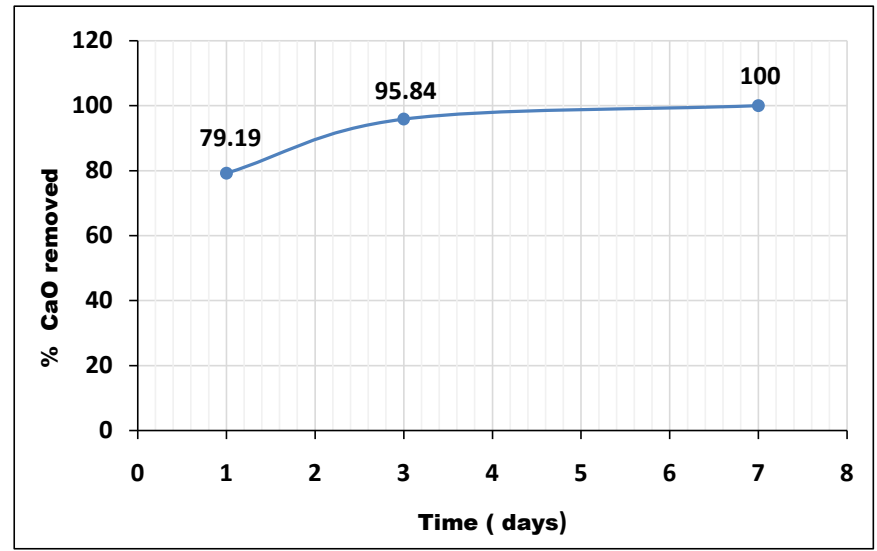

Figure 4. Saturated lime test results.

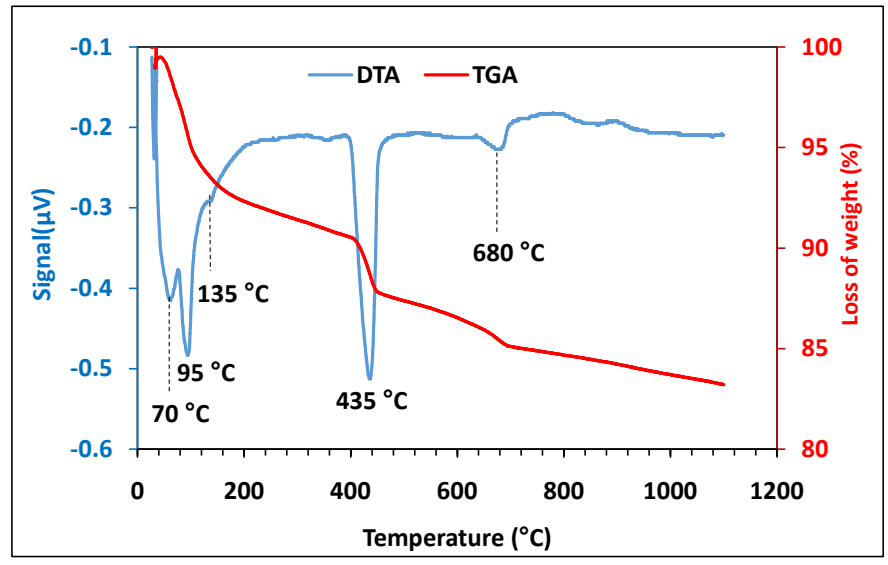

Figure 5. Thermograms DTA-TGA of residues containing cement after Frattini test. 


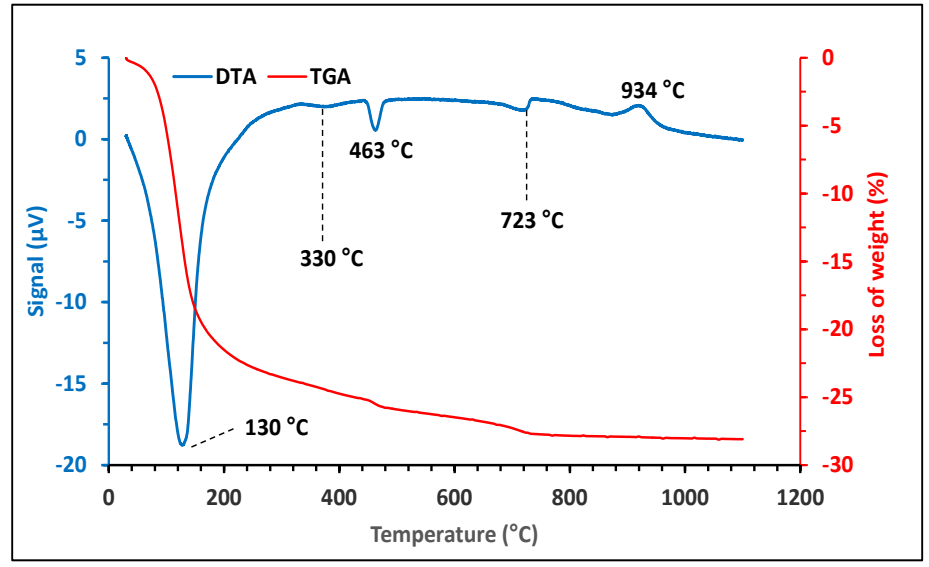

Figure 6. Thermograms DTA-TGA of residues containing cement-RHA after Frattini test.

The endothermic peak around $330^{\circ} \mathrm{C}$ indicates the presence of hydrate $\mathrm{C}_{3} \mathrm{ASH}_{6}$, which shows that the cement-RHA mixture allows the formation of new hydrate. Between $435^{\circ} \mathrm{C}$ and $465^{\circ} \mathrm{C}$ we have the peak of dehydration of portlandite. This peak is more intense in the cement than in the cement-RHA mixture, which proves the strong release of portlandite by cement and its consumption by RHA, hence the pozzolanic reactivity of RHA [22]. The fixation of portlandite by pozzolan or the reduction of portlandite in the cement-water-pozzolan system may be due mainly to the dilution effect and the pozzolanic effect [8]. Firstly, the dilution effect is defined as the effect caused by the dilution of the cement in the mixture resulting from the partial replacement of the cement with pozzolan, which results in the release of the portlandite. Then, the pozzolanic effect is defined as the effect caused by the reaction between pozzolan and portlandite released by hydration of the cement in order to necessarily form CSH gels. Nevertheless, the effectiveness of a pozzolan in such a system is rather dependent of the pozzolanic effect than the dilution effect, since the latter is independent of the nature of the pozzolan used. The peaks at $680^{\circ} \mathrm{C}$ and $720^{\circ} \mathrm{C}$ are due to decarbonation [23]. That is the formation of calcite following the reaction involving the portlandite produced by hydration of cement and the carbon dioxide of the atmosphere according to the Reaction 4 [10]:

$$
\mathrm{Ca}(\mathrm{OH})_{2}+\mathrm{CO}_{2} \rightarrow \mathrm{CaCO}_{3}+\mathrm{H}_{2} \mathrm{O}
$$

The only exothermic peak at $930^{\circ} \mathrm{C}$ at the mixture level could be likened to the presence of tridymite in RHA.

Given that RHA has a pozzolanic activity, it can then be used as pozzolan in the production of the mortars.

\subsection{Evolution of the Mechanical Strength of Mortars}

In order to monitor the development of the mechanical behaviour of the mortars, the flexural and compressive strength of the mortars (Figure 7) was determined 28 days after their formulation. The analysis of Figure 7 shows that the reference mortar $\mathrm{B}_{0}$ that does not contain RHA has a low mechanical strength 
compared to the mortars modified with the RHA. Thus the addition of the RHA contributes to the mechanical strength increase. In addition, the mechanical strength of mortars increases with the rate of RHA up to $20 \%$ substitution. With $25 \%$ substitution the resistance drops very slightly. The optimal substitution percentage for a better resistance is therefore $20 \%$. This result is in agreement with those obtained by several authors [24]. To have a better understanding of the mortars mechanical behaviour, the SEM images were made on the pieces of mortars obtained after mechanical strength (Figure 8) and then on the powders of the same mortars (Figure 9).

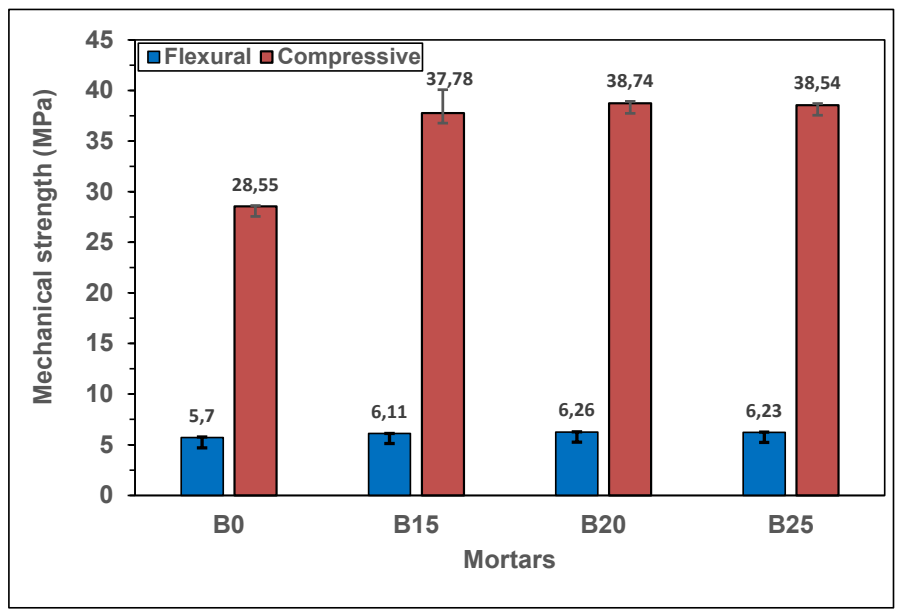

Figure 7. Flexural and compressive strength of mortars after 28 days of curing.
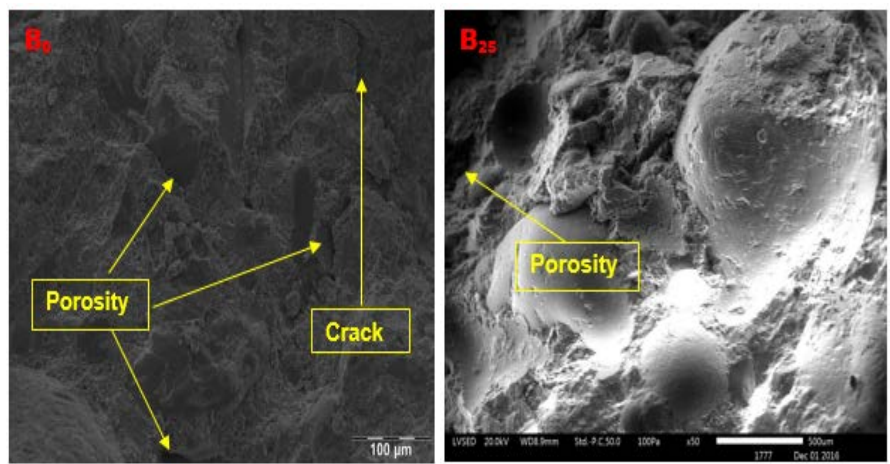

Figure 8. SEM micrographs of mortars B0 and B25.
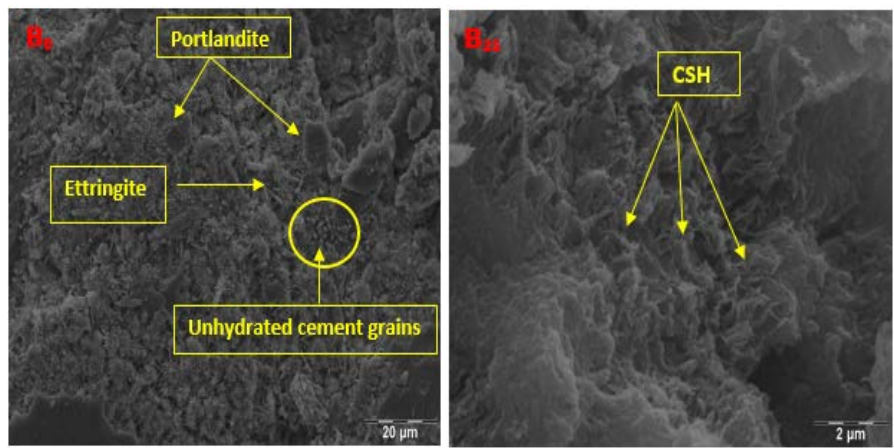

Figure 9. SEM images of mortars B0 and B25 powders. 
The SEM image of the $\mathrm{B}_{0}$ mortar (Figure 8) shows a material with a few pores and cracks. On the other hand, the image of mortar $B_{25}$ shows a fairly homogeneous material having less pores and cracks than $\mathrm{B}_{0}$. As for the powders (Figure 9), some hydration products of clinker compounds such as portlandite $(\mathrm{CH})$ and ettringite $\left(\mathrm{C}_{6} \mathrm{~A} \overline{\mathrm{S}} \mathrm{H}_{32}\right)$ as well as unhydrated cement grains on $\mathrm{B}_{0}$ may be observed. However, $\mathrm{CSH}$ is present in the form of honeycombs in the $\mathrm{B}_{25}$ mortar.

These observations provide indication that the improvement of the mechanical properties of the mortars could be due to the filler effect of RHA and the presence of CSH. First RHA can be inserted between the grains of the cement because of its fine size, which reduces the pores and so makes the material more compact and resistant [4]. Moreover, according to several authors, the mechanical strength of cementitious materials is due to the presence of CSH [4] [10] [21]. Indeed, CSH results from the pozzolanic reaction between the portlandite released by the cement and the amorphous silica of the RHA. Their presence makes the material homogeneous with fewer pores.

\section{Conclusion}

The calcination of rice husk at $680^{\circ} \mathrm{C}$ for 5 hours has permitted to obtain ash rich in amorphous silica (96.84\%). This RHA has a pozzolanic activity with a lime fixation rate of $100 \%$ after only 7 days of treatment. The partial substitution of the cement by the RHA results in the formation of calcium silicate hydrate $(\mathrm{CSH})$ and aluminates of $\mathrm{C}_{3} \mathrm{ASH}_{6}$ types due to the pozzolanic reactivity between the amorphous silica of RHA and the portlandite released by the hydration of the cement. The presence of RHA in the mortars improves their mechanical strength due to the filler effect of RHA and the presence of CSH.

\section{Acknowledgements}

We are grateful to Younoussa Millogo of University Nazi Boni of Burkina Faso for his implication in the characterization of samples and for his advice during the writing of this article.

\section{Conflicts of Interest}

The authors declare no conflicts of interest regarding the publication of this paper.

\section{References}

[1] Laoufi, L., Senhadji, Y., Banazzouk, A., Langlet, T., Mouli, M., Laoufi, I. and Benosman, A.S. (2016) Evaluation de la durabilité de mortiers pouzzolaniques exposés à une attaque chimique. Journal of Materials and Environmental Science, 7, 1835-1845.

[2] American Society for Testing and Material (ASTM) C-125 (2007) Standard Terminology Relating to Concrete Aggregates.

[3] Seynou, M., Millogo, Y., Zerbo, L., Sanou, I., Ganon, F., Ouedraogo, R. and Kaboré, K. (2016) Production and Characterization of Pozzolan with Raw Clay from Burki- 
na Faso. Journal of Minerals and Materials Characterization and Engineering, 4, 195-209. https://doi.org/10.4236/jmmce.2016.43018

[4] Dao, K., Ouedraogo, M., Millogo, Y., Aubert, J.-E. and Gomina, M. (2018) Thermal, Hydric and Mechanical Behaviours of Adobes Stabilized with Cement. Construction and Building Materials, 158, 84-96. https://doi.org/10.1016/j.conbuildmat.2017.10.001

[5] Chaib, O., Mouli, M., Hanifi, M. and Hamadache, M. (2016) Etude de l'influence des paramètres de la pouzzolane naturelle sur la résistance mécanique des mortiers à base de ciments composés. Journal of Materials and Environmental Science, 7, 422-428.

[6] Cordeiro, G.C., Filho, R.D.T. and Fairbairn, E.M.R. (2009) Use of Ultrafine Rice Husk Ash with High-Carbon Content as Pozzolan in High Performance Concrete. Materials and Structures, 42, 983-992. https://doi.org/10.1617/s11527-008-9437-Z

[7] Saraswathy, V. and Song, H.-W. (2007) Corrosion Performance of Rice Husk Ash Blended Concrete. Construction and Building Materials, 21, 1779-1784. https://doi.org/10.1016/j.conbuildmat.2006.05.037

[8] Venkatanarayanan, H.K. and Rangaraju, P.R. (2015) Effect of Grinding of Low Carbon Rice Husk Ash on the Microstructure and Performance Properties of Blended Cement Concrete. Cement and Concrete Composites, 55, 348-363. https://doi.org/10.1016/j.cemconcomp.2014.09.021

[9] Millogo, Y., Hajjaji, M., Ouedraogo, R. and Gomina, M. (2008) Cement-Lateritic Gravels Mixtures: Microstructure and Strength Characteristics. Construction and Building Materials, 22, 2078-2086. https://doi.org/10.1016/j.conbuildmat.2007.07.019

[10] Sanou, I., Seynou, M., Zerbo, L. and Ouedraogo, R. (2019) Mineralogy, Physical and Mechanical Properties of Adobes Stabilized with Cement and Rice Husk Ash. Science Journal of Chemistry, 7, 1-10. https://doi.org/10.11648/j.sjc.20190701.11

[11] Harish, K.V. and Rangaraju, P.R. (2013) Material Characterization Studies on Low-and High-Carbon Rice Husk Ash and Their Performance in Portland Cement Mixtures. Advances in Civil Engineering Materials, 2, 266-287. https://doi.org/10.1520/ACEM20120056

[12] Norme, ASTM Standard, C 618 (2008) Standard Specification for Coal Fly Ash and Raw or Calcined Natural Pozzolan for Use in Concrete. Annual Book of ASTM standards, ASTM International, West Conshohocken, PA.

[13] Erika, Y.N., Moisés, F., Sagrario, M.-R., Sérgio, F.S., Michelle, S.R., Olga, R. and Holmer, S.J. (2014) Characterization and Properties of Elephant Grass Ashes as Supplementary Cementing Material in Pozzolan/Ca(OH) ${ }_{2}$ Pastes. Construction and Building Materials, 73, 391-398. https://doi.org/10.1016/j.conbuildmat.2014.09.078

[14] Donatello, S., Tyrer, M. and Cheeseman, C.R (2010) Comparison of Test Methods to Assess Pozzolanic Activity. Cement and Concrete Composites, 32, 121-127. https://doi.org/10.1016/j.cemconcomp.2009.10.008

[15] NF P15-403 (1996) Sable normal et mortier normal. AFNOR-Paris.

[16] Seynou, M., Ouedraogo, R., Millogo, Y., Traore, K. and Bama, B.C.A. (2009) Geotechnical, Mineralogical, Chemical and Mechanical Characterization of Clay Raw Material from Korona (Burkina Faso). Journal de la Société Ouest Africaine de Chimie, 27, 9-19.

[17] NF P15-471 (1990) Méthodes d'essais des ciments: Détermination des résistances mécaniques. AFNOR-Paris. 
[18] Sanou, I., Seynou, M., Zerbo, L., Millogo, Y., Ouedraogo, R. and Sana, A. (2017) Evaluation of Pozzolanic Activity of Illitic and Lateritic Raw Materials from Burkina Faso. Chemical Science International Journal, 18, 1-13. https://doi.org/10.9734/CSJI/2017/30995

[19] Massazza, F. (2007) Pozzolana and Pozzolanic Cements. In: Hewlett, P.C., Ed., Lea’s Chemistry of Cement and Concrete, 4th Edition, Elsevier, London, 471-635. https://doi.org/10.1016/B978-075066256-7/50022-9

[20] Walker, R. and Pavia, S. (2010) Physical Properties and Reactivity of Pozzolans, and Their Influence on the Properties of Lime-Pozzolan Pastes. Materials and Structures, 44, 1139-1150. https://doi.org/10.1617/s11527-010-9689-2

[21] Cassagnabere, F., Escadeillas, G. and Mouret, M. (2009) Study of the Réactivity of Cement/Metakaolin Binders at Early Age for Specific Use in Steam Cured Precast Concrete. Construction Building and Materials, 23, 775-784.

https://doi.org/10.1016/j.conbuildmat.2008.02.022

[22] Manjit, S. and Mridul, G. (2006) Reactive Pozzolana from India Clays-Their Use in Cement Mortars. Cement and Concrete Research, 36, 1903-1907.

https://doi.org/10.1016/j.cemconres.2004.12.002

[23] Moropoulou, A., Bakolas, A. and Aggelakopoulou, E. (2004) Evaluation of Pozzolanic Activity of Natural and Artificial Pozzolans by Thermal Analysis. Thermochimie Acta, 420, 135-140. https://doi.org/10.1016/j.tca.2003.11.059

[24] Abalaka, A.E. and Okali, O.G. (2013) Influence of Water-Binder or Normal Strength Concrete with Rice Husk Ash. International Journal of Sciences, 2. http://www.ij.Sciences.com 